\title{
Access vs. Ownership: Do We Have to Make a Choice?
}

\section{Laura Townsend Kane}

The library profession is currently facing a dilemma that could ultimately impact the future of libraries and librarianship. In this rapidly changing age of technology, the traditional view of libraries as "warehouses of information" is being challenged by the more modern view of them as "providers of access to information." A conflict has emerged between those in the profession who believe ownership of information is most important and those who believe access to information is most important. It would seem that every library must make a choice between the two. However, there is a third option that could possibly satisfy everyone as well as ensure that libraries continue to be viable and important information centers in the future. This is the "access and ownership" view.

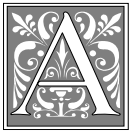

recent video produced by OCLC entitled Cruisin' That Information Superhighway with Mr. Dewey and His Dot clearly illustrates a dilemma that the library profession is facing today. ${ }^{1}$ The "Futurists" in the video, portrayed as menacing robotic monsters, represent those who firmly believe that libraries will be nonexistent in the near future. In their point of view, there will be no books and no print formats. Everything will be electronically accessible from home computers, and librarians will no longer be needed. By contrast, the cartoon figure of Melvil Dewey and his "Dot" represent those who believe that libraries will continue to exist as long as there are people who thirst for knowledge. The phrase commonly used to describe these two opposing views is "access vs. ownership." The question librarians must seriously face today is: Which is more important, ownership of information or provision of access to information? Which of the two will be the most likely to satisfy the information needs of tomorrow's patrons?

Perhaps it is time for librarians to recognize that a choice does not have to be made. It is not necessary to choose between access and ownership, because libraries of the future can be made stronger by a delicate balance between the two. Information owned and information accessed will become partners that will supplement and build on one another, transforming libraries as we know them into the dynamic information centers of the future.

\section{Background}

To uncover the source of the access vs. ownership conflict, one must first look back at the early history of libraries. Since the beginning of time, "the primary ob-

Laura Townsend Kane is a Catalog Librarian in Library and Information Resources at the School of Medicine, University of South Carolina, Columbia, e-mail: laura@dcsmserver.med.sc.edu. 
jective of any library has been to collect and house information of interest to the specific clientele which it serves."2 Libraries have assumed responsibility for consolidating and storing information and for serving as warehouses of knowledge. "As early as the third millennium B.C. records on clay tablets were stored in a temple in Babylon," constituting the first known library in history. ${ }^{3}$ The library in Alexandria around 300 B.c., known as the greatest library in antiquity, housed vast collections of papyrus and vellum scrolls arranged and stored in a systematic manner. Even today, the word library is defined as "a collection of books used for reading or study, or the building or room in which such a collection is kept." ${ }^{4}$ With the passage of time, from the era of that

\section{Serial subscription costs have skyrocketed, forcing libraries to cut back on other budgeted areas in order to simply maintain those subscriptions.}

first library in Babylon until today, it has become common knowledge that the larger a library's collection, the better the library. This is why emphasis is always placed on the words collection and holdings and the numbers or statistics associated with them. In a recent article in the Bulletin of the Medical Library Association, Nina W. Matheson makes reference to a famous picture of Paul Erhlich sitting in his office surrounded by stacks of papers and books. "Even today," she writes, "a wall of books and stacks of paper are used as background to convey the idea of authority, intellectual life, possession of knowledge, scientific merit." ${ }^{5}$ The belief that the quality of a library is determined by the quantity of materials in its collection (i.e., "the bigger, the better") has become the library's "thorn in the flesh," for it is more and more difficult for today's libraries to meet the demands that such a belief imposes.
With the information explosion in the twentieth century, it has become evident that libraries are no longer capable of purchasing or "collecting" the vast amount of materials that would satisfy all the information needs of every patron. As we race toward the twenty-first century, it would seem that as massive quantities of information become more readily available, the resources to purchase them diminish. Not only are library budgets being cut for various reasons, but the costs of library materials are increasing at an alarming rate as well, far above the financial capabilities of libraries today. Serial subscription costs have skyrocketed, forcing libraries to cut back on other budgeted areas in order to simply maintain those subscriptions. Figure 1 illustrates that, since 1991, the total number of serial subscriptions in medical school libraries in the United States and Canada has decreased steadily, while serial expenditures have increased. In 1993-94, medical school libraries paid $\$ 4.7$ million more for serials than in 199293, but had 6,056 fewer serial subscriptions among all the libraries. ${ }^{6}$ It is evident that today's libraries are faced with the constant struggle of simply maintaining the collections they have, much less developing them. ${ }^{7}$

To offset the problems created by the information explosion coupled with insufficient budgets and increasing costs, libraries have been forced to pursue other methods of fulfilling the information needs of patrons. Although the concepts of ownership and collecting have been deeply embedded in all that we do in libraries, the trend toward "access" began essentially as a survival mechanism. If a patron is in need of an item that is not available locally, most libraries are willing to find that item, no matter where it is located. To do anything less would decrease the value of libraries in the eyes of the patron, who would then look elsewhere for the needed material. The rapid rate of increase of interlibrary loans (ILLs) is a solid example of this trend toward 
FIGURE 1

Subscriptions vs. Expenditures (1991-94)

Serial Subscriptions

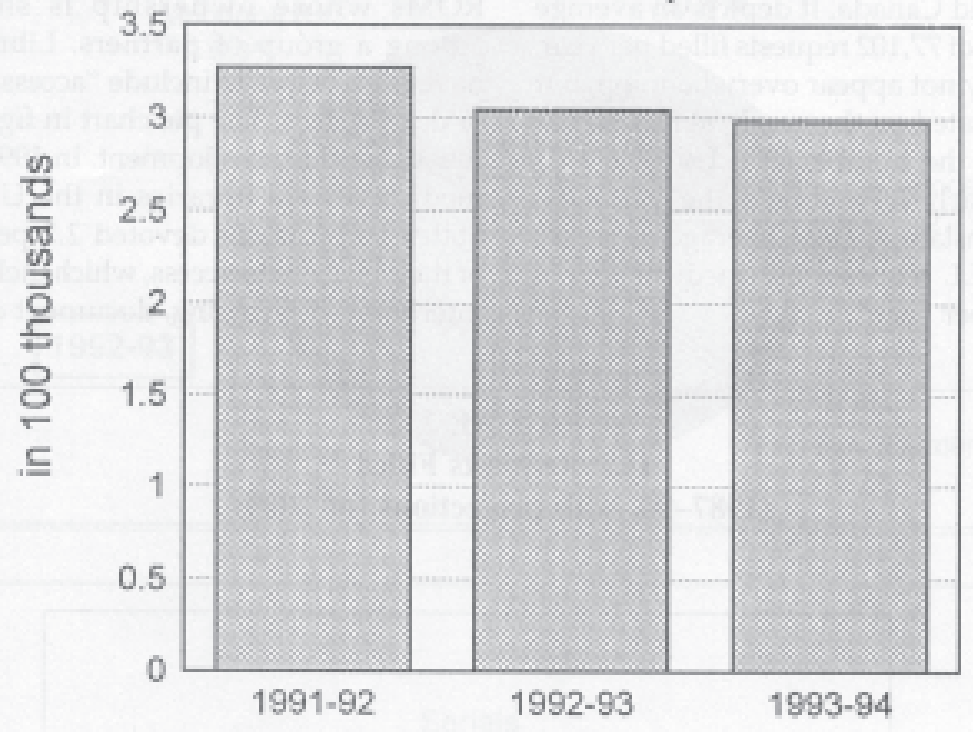

Serial Expenditures

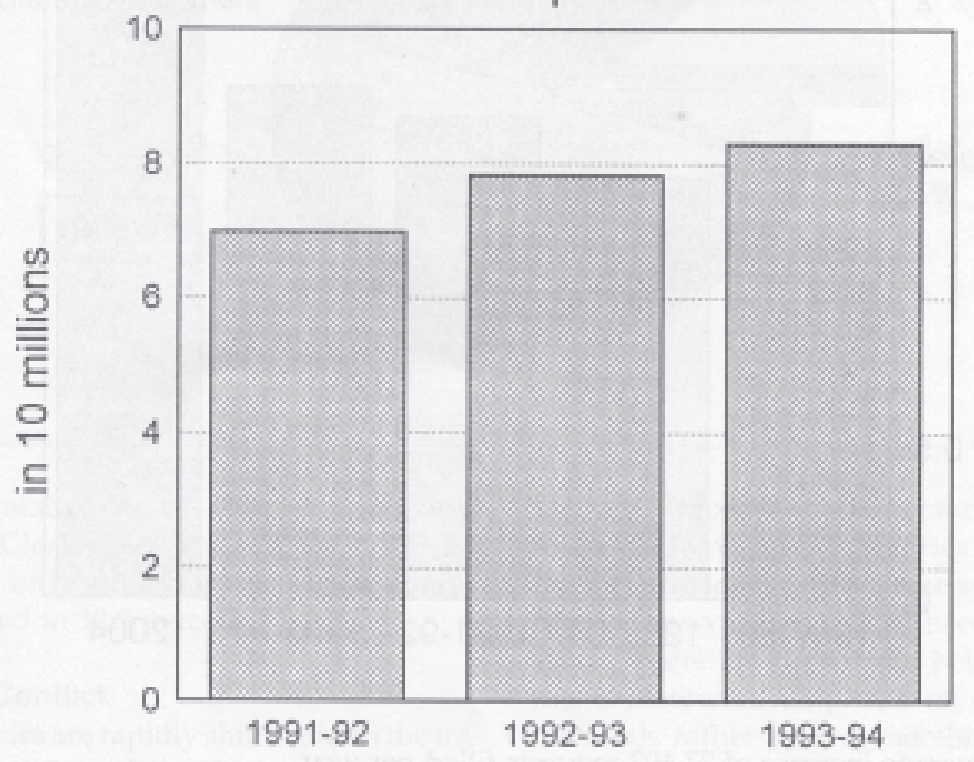


access. Figure 2 illustrates the steady increase of ILLs filled among medical school libraries in the United States and Canada. It depicts an average increase of 77,102 requests filled per year. This may not appear overwhelming, but as illustrated on the graph, at this rate of increase the number of ILLs filled will reach nearly 2.5 million in the year 2004. This translates into an average of nearly 18,000 ILL requests per medical school library per year! ${ }^{8}$

ILLs are one example of accessed materials. Other forms of access that librar- ies rely on at an ever-increasing rate are: document delivery, computer databases at remote sites, and materials such as CDROMs whose ownership is shared among a group of partners. Libraries have even begun to include "access" as a budgeted item. The pie chart in figure 3 illustrates this development. In 1992-93, medical school libraries in the United States and Canada devoted 2.7 percent of their budgets to access, which included interlibrary borrowing, document delivery, database access charges, and Copyright Clearinghouse charges. In 1993-94, after only one

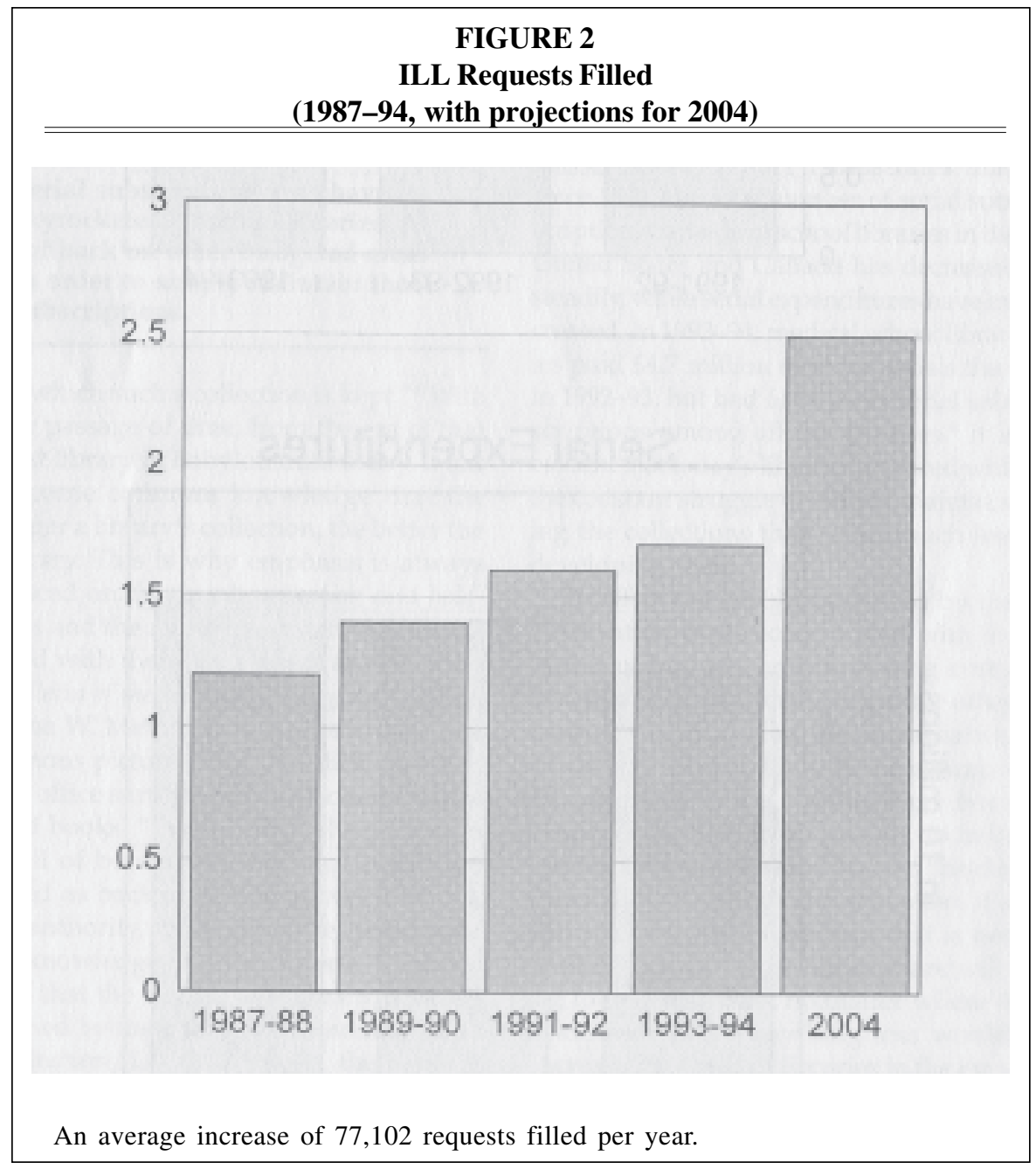




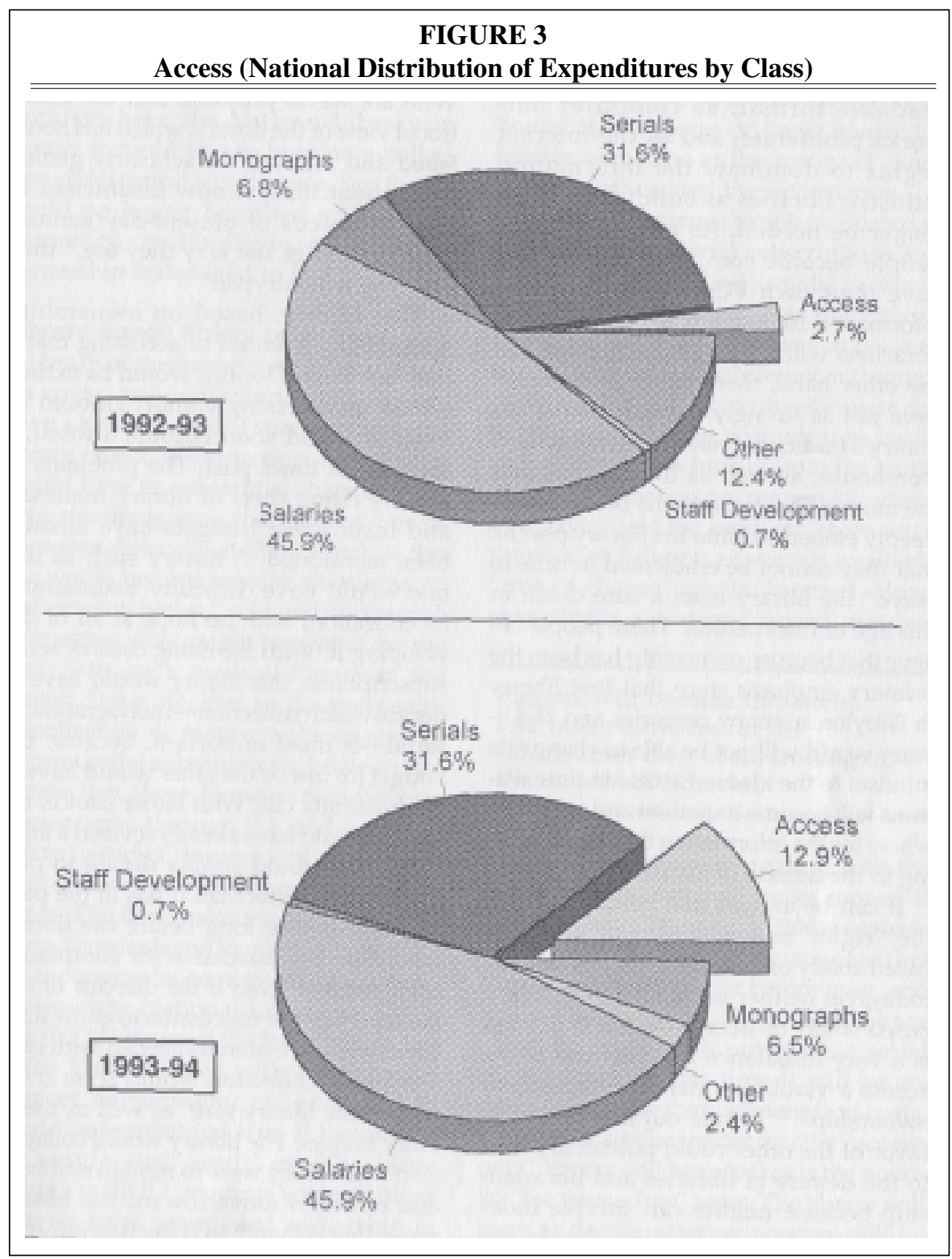

year, this percentage jumped to 12.9 percent. $^{9}$

\section{The Conflict}

Libraries are rapidly shifting from the traditional "warehouse" view, where they serve as information collectors, to the more modern view of libraries as infor- mation providers. This is where the conflict "access vs. ownership" becomes obvious. There are those who believe that this shift toward emphasis on access to materials rather than ownership of materials will eventually lead to the demise of the library and librarianship. Some have claimed that as materials become 
increasingly available in machine-readable format, as computer networks proliferate, and as the Internet begins to dominate the information industry, libraries as buildings will no longer be needed. As more and more people become computer literate and have their own PCs with links to the information highway, it is predicted that librarians will no longer be needed. On the other hand, there are those who believe just as strongly that the idea of the library's traditional role as an information storehouse, as well as the concept that the more a library owns the better, are so deeply embedded into the library psyche that they cannot be eradicated in time to "save" the library from a sure death in this age of information. These people believe that because ownership has been the primary emphasis since that first library in Babylon so many centuries ago, the library world will not be able to change its mindset to the ideas of access in time. Patrons will become impatient and turn elsewhere for the information they need, leading to the demise of libraries.

It can be argued that neither view is the "right" one. The idea of a library based solely on ownership is not feasible today, yet neither is the idea of a library based solely on access. "What is needed is a way to balance the two and make access a viable partner to complement ownership." ${ }^{10}$ To rule out one option in favor of the other could potentially lead to the demise of libraries and librarianship because neither can survive independently. Let us examine closely the following two scenarios.

\section{Library Based Solely on Ownership}

Imagine a library in 1996 whose administrators refuse to take part in this trendy business called "access." Perhaps they claim that once people have had enough of technology and computers, they will quickly return to reliable print format. Libraries have survived and even flourished for centuries without changing radically. Why should they change now?
Who are we to presume that the traditional view of the library, which has nourished and assisted the scholarly genius throughout time, is now insufficient to meet the needs of present-day genius? "We like things the way they are," they say. "We will survive."

This library, based on ownership, without any avenues of accessing materials not owned locally, would be extinct within an alarmingly short amount of time. It would soon become a fossil, a memory of times past. The problems of rapidly rising costs of library materials and insufficient budgets have already been mentioned. A library such as this one would have difficulty maintaining its collection, with no hope at all of developing it. With the rising costs of serial subscriptions, this library would have to decide which collection-monographic or serialis most important, because the budget for one or the other would have to be drastically cut. With either choice, the library would have already severed a limb. Perhaps it would simply decide to purchase fewer items than it has in the past. It would not be long before the library would be bombarded with complaints from patrons. Even if the director of this library made the concession to allow ILLs, the volume of materials needed with such a crippled collection would soon overwhelm the library staff, as well as the library budget. The library would collapse.

If this library were to remain stubborn and refuse to move toward the idea of providing rather than collecting information, it would have only two options left. The first would be to become a special library, purchasing materials in only one or two subject areas and limiting the population it serves. Even this option would soon have its problems. Special libraries must often deal with information that is dynamic, not static. Without proper communication among libraries or links to the information highway, this library's materials would soon become out of date. The second option for this library would 
be to simply become an archive. Like the Vatican Library in Rome, it could opt to become a collection of historical significance. But then it could no longer be called a library. In summary, the library based solely on ownership is destined to fail.

\section{Library Based Solely on Access}

A library of the future that is based solely on access, not ownership, would indeed have a better chance of surviving than the library based on ownership. However, it would have its substantial share of problems stemming from the fact that it owns no materials locally. A library such as this one would become more of a business, an "information broker," cold and impersonal.

Imagine what might happen if, by the year 2010, each medical library in the United States decides to do away with its collection of monographs as well as all print serial subscriptions. Logic would dictate that these libraries could obtain monographs through ILL and access to journal articles through online full-text ejournals on various networks or the Internet. The first major problem crops up when libraries begin to rely solely on ILLs for monographs requested by patrons. Suppose the National Library of Medicine (NLM) is one of the few libraries left in the United States with a full health sciences monographic collection. NLM would be bombarded with ILL requests. No single staff could ever be large enough to fill ILL requests when all other libraries have abandoned ownership in favor of access. If interlibrary loans were filled at all in this situation, patrons would be forced to wait months for a book they requested. To look at this problem from another angle, one could argue that to rely on one or two major centers for the provision of ILL materials would be the same as putting power into the hands of a few. If information is knowledge and knowledge is power, those few libraries left who owned monographs would have complete control over the dissemination of the knowledge held bound in the pages of those books. Libraries would be at the mercy of those who actually owned the information.

A second ominous problem, related to cancelling print serial subscriptions and relying on full-text e-journals, is one of cost. Most librarians assume that cancelling print serial subscriptions in favor of accessing them on the Internet or through other networks is going to eliminate the problem of soaring subscription costs. This could not be further from the truth. The fact is: "there is no free service; someone pays." 11 At the moment, there are a number of full-text e-journals available "free of charge" on the Internet. However, this is a luxury that will not last long. Publishers are struggling with the issue of how they will make money if there is basically one file that everyone can ac-

\section{Patrons will become impatient and turn elsewhere for the information they need, leading to the demise of libraries.}

cess. ${ }^{12}$ It is almost a guarantee that they will figure this out before long, and when that happens, libraries will once again be faced with outrageous serial costs. However, this time it will be access costs rather than subscription costs.

Another similar matter that the "accessonly" library will have to face is the popular "fee versus free" issue. The library will have to decide whether charges will be involved. If so, for which services will fees be collected? Today, it is common for libraries to charge patrons for ILLs and for database searching. The cost of access has frequently been passed on to users. ${ }^{13}$ It was reasoned that these were extra services and, therefore, it was appropriate to charge for them. ${ }^{14}$ In the library of the future where accessed materials are the only ones available, will it be fair to charge library patrons for anything? Regarding the issue of ILL charges, Herbert S. White wrote: "Charg- 
ing for interlibrary loan represents, for me, a logical absurdity . . . it amounts to double penalization for the user." ${ }^{15} \mathrm{He}$ reasoned that patrons are not only "penalized" by having to wait for something the library does not own, but they also must face a second penalty - the ILL charge. Along these same lines, should library users be penalized for the shift from ownership to access? If not, will the library be able to absorb the costs of ILL and database searching? It is hard enough to justify money these days when there is not a physical item to account for, so how will these access-only libraries persuade their parent organizations to grant them sufficient resources?

Further potential pitfalls for the accessonly library would be speed of access and elimination of browsing. ${ }^{16}$ With the elimination of print information that is immediately available, the library patron will have to pay the "penalty" of waiting for an item either ordered through ILL or located in electronic format. Additionally, library patrons who have become accustomed to browsing the book stacks will no longer be able to indulge in this activity. It would be naive to believe that library patrons would accept such radical changes without complaint.

In short, the library based solely on access has many obstacles and problems awaiting it. It is easy to see how such a library could fail just as dismally as the library based solely on ownership.

\section{The Compromise}

"Most libraries of today cannot be libraries of the future," stated Matheson. ${ }^{17}$ However, by taking some significant steps toward positive change, the libraries of today can remain viable information centers in the twenty-first century. Changing library operations to provide access to information is the most essential step in securing the success of the library of the future, because "if libraries will not provide access to information, our patrons will obtain that access else- where." 18 This readjustment toward access, however, does not need to be at the expense of ownership. "It is time to put aside access versus ownership and concentrate on access and ownership." 19 The successful library of the future will consist of a delicate balance between materials that are owned and those that are accessed. The quality of these future libraries will not be determined by size but, rather, by how effectively they fulfill the needs of the patron.

To achieve success, the future library should begin with a well-defined collection development policy. Each library's specific policy will vary, but some components should be common to all. First of all, the library should maintain a core collection based on the standard "20 percent" rule, which is that 20 percent of the collection that will satisfy 80 percent of the information needs of patrons. ${ }^{20}$ This core collection of high-demand materials can be established through careful consideration of circulation statistics. The library should then maintain in its collection material that is tailored to the library's unique clientele. In other words, the library should continue to purchase items that are frequently used by its patrons, but cannot be obtained except by owning them. For materials that are in moderate to low demand, libraries should purchase access to the information rather than the information itself. This "accessed" information will originate from either ILLs and document delivery or electronic sources such as full-text database services, CD-ROM products, and Internet resources. It is essential that electronic access be incorporated into the library's collection development policies. Finally, the library of the future should strive to establish shared collection agreements and to work cooperatively with other libraries. By following these guidelines, "access strategies will continue to be enhancements of or supplements to ownership." 21

The perfectly balanced access and ownership library will not appear overnight. It will require continual, extensive studies 
on the use of materials owned, as well as the demand for accessed materials in order to ensure that user needs are being met in a sufficient and timely manner. The balance between the two must be carefully monitored and constantly modified to keep up with the fast pace of the information industry. Most definitely, it is a challenge that we as librarians must face with determination, but once the library of the future is established, it will undoubtedly be recognized by all as an invaluable service in the information age. "It is the demand for information and the need for specific knowledge that causes libraries." 22 This demand will never disappear. Humankind will never quench its thirst for knowledge. Ensuring that librar- ies continue to meet this demand for information secures the future of librarianship forever. If the choice "access and ownership" can be made instead of "access vs. ownership," librarians will have delivered

\section{The library should continue to purchase items that are frequently used by its patrons, but cannot be obtained except by owning them.}

libraries from certain extinction. By combining the best features of both the traditional warehouse idea and the electronic library idea, libraries in the future will not only survive but flourish to become the hub of the information community.

\section{Notes}

1. Cruisin' That Information Superhighway with Mr. Dewey and His Dot (Dublin, Ohio: OCLC Online Computer Library Center, 1994), videocassette.

2. David Tyckoson, "Access vs. Ownership: Changing Roles for Librarians," Reference Librarian 34 (1991): 37.

3. Encyclopaedia Britannica, 1993 ed., s.v. "libraries."

4. Ibid.

5. Nina W. Matheson, "The Idea of the Library in the Twenty-First Century," Bulletin of the Medical Library Association 83, no. 1 (Jan. 1995): 3.

6. Association of Academic Health Sciences Library Directors, Annual Statistics of Medical School Libraries in the United States and Canada, 15th-17th eds. (Seattle, Wash.: AAHSLD, 198394).

7. Thomas W. Shaughnessy, "From Ownership to Access: A Dilemma for Library Managers," Journal of Library Administration 14, no. 1 (1991): 1-7.

8. AAHSLD, Annual Statistics of Medical School Libraries.

9. Ibid.

10. Irene B. Hoadley, "Access vs. Ownership: Myth or Reality," Library Acquisitions: Practice and Theory 17 (1993): 192.

11. Ibid., 193.

12. Ibid., 191-95.

13. Shaughnessey, "From Ownership to Access," 1-7.

14. Hoadley, "Access vs. Ownership," 191-95.

15. Herbert S. White, "Ownership Is Not Always Availability-Borrowing May Not Satisfy Access Needs," in Access to Scholarly Information: Issues \& Strategies, ed. Sul H. Lee (Ann Arbor, Mich.: Pierian Pr., 1985), 3.

16. Anthony W. Ferguson and Kathleen Kehoe, "Access vs. Ownership: What Is Most Cost Effective in the Sciences," Journal of Library Administration 19, no. 2 (1993): 89-99.

17. Matheson, "The Idea of the Library," 5.

18. Tyckoson, "Access vs. Ownership," 44.

19. Hoadley, "Access vs. Ownership," 195.

20. Sheila S. Intner, "Differences between Access vs. Ownership," Technicalities 9, no. 9 (Sept. 1989): 5-8.

21. Stuart James, "Ownership and Access, Database and OPAC: Present and Future Opportunities for Academic Libraries," Library Review 39, no. 4 (1990): 27.

22. Matheson, "The Idea of the Library," 5. 